\title{
KAJIAN PEMBUATAN PERMEN SUSU KARAMEL DENGAN \\ PENAMBAHAN PEPPERMINT OIL (MENTHA PIPERITA) DAN EKSTRAK KULIT MANGGIS (GARCINIA MANGOSTANA L)
}

\section{(The Study Of Making Caramel Milk Candy With The Addition Of Peppermint Oil (Mentha Piperita) And Manggost Skin Extract (Garcinia Mangostana L))}

\author{
Febi Rizki Adinda ${ }^{1}$, Cut Nilda ${ }^{1}$, Fahrizal $^{1}{ }^{*}$ \\ ${ }^{1}$ Program Studi Teknologi Hasil Pertanian, Fakultas Pertanian, Universitas Syiah Kuala \\ *Corresponding author: fahrizal.z.@unsyiah.ac.id
}

\begin{abstract}
Abstrak. Pengolahan susu menjadi permen karamel dengan penambahan ekstrak kulit manggis dan peppermint oil sebagai antioksidan dan flavor minty sangat menarik, pembuatan permen karamel susu dengan penggabungan dua komponen bahan tersebut menjadikan produk permen tersebut bernilai gizi dan menyehatkan. Penelitian ini bertujuan untuk mempelajari pembuatan permen karamel dengan penambahan ekstrak kulit manggis dan peppermint oil, mengetahui pengaruh penambahan peppermint oil dan ekstrak kulit manggis terhadap mutu fisik dan kimia dari permen karamel susu. Rancangan Acak Lengkap (RAL) faktorial dengan 2 faktor, yaitu penambahan ekstrak kulit manggis dan peppermint oil. Faktor penambahan ekstrak kulit manggis terdiri dari 3 (tiga) taraf yaitu penambahan ekstrak kulit manggis $50 \mathrm{~g}$ (M1), $60 \mathrm{~g}$ (M2), $70 \mathrm{~g}$ (M3), faktor kedua yaitu penambahan peppermint oil yang terdiri 3 (tiga taraf) yaitu $1 \mathrm{ml}(\mathrm{P} 1), 2 \mathrm{ml}(\mathrm{P} 2)$ dan $3 \mathrm{ml}(\mathrm{P} 3)$. Nilai rata-rata aktivitas antioksidan sebesar $80,48 \%$. Nilai rata-rata kadar air pada penelitian ini sebesar 4,82\%. Nilai rata-rata gula reduksi pada penelitian ini sebesar 2,19\%. Penilaian rata-rata untuk warna permen yaitu sebesar 3,69, penilaian rata-rata untuk aroma yaitu sebesar 3,58, penilaian rata-rata untuk tekstur yaitu sebesar 3,57 dan penilaian tertinggi untuk rasa yaitu sebesar 4,34. Secara statistik, hasil penelitian menunjukkan bahwa interaksi antar faktor berpengaruh nyata $(\mathrm{P} \leq 0,01)$ terhadap antioksidan yang dihasilkan. Faktor konsentrasi ekstrak kulit manggis dan peppermint oil berpengaruh nyata $(\mathrm{P} \leq 0,05)$ terhadap terhadap rasa dari permen karamel.
\end{abstract}

Kata kunci : Permen karamel, Ekstrak kulit manggis, peppermint Oil.

Abstract. Abstract. The processing of milk into caramel candy with the addition of mangosteen peel extract and peppermint oil as antioxidants and minty taste is very interesting, making milk caramel candy by combining these two components makes the product nutritionally feasible and healthy. This study aims to study the manufacture of caramel candy with the addition of mangosteen peel extract and peppermint oil, to determine the effect of adding peppermint oil and mangosteen peel extract to the physical and chemical properties of milk caramel candy. Completely Randomized Design (CRD) factorial with 2 factors, namely the addition of mangosteen peel extract and peppermint oil. The addition factor of mangosteen peel extract consists of 3 (three) levels, namely the addition of mangosteen peel extract $50 \mathrm{~g}$ (M1), $60 \mathrm{~g}$ (M2), $70 \mathrm{~g} \mathrm{(M3),} \mathrm{the} \mathrm{second} \mathrm{factor} \mathrm{is} \mathrm{the} \mathrm{addition} \mathrm{of}$ peppermint oil which consists of 3 (three levels) namely $1 \mathrm{ml}(\mathrm{P} 1), 2 \mathrm{ml}(\mathrm{P} 2)$ and $3 \mathrm{ml}(\mathrm{P} 3)$. The average value of antioxidant activity is $80.48 \%$. The average value of water content in this study was $4.82 \%$. The average value of reducing sugar in this study was $2.19 \%$. the average for candy is 3.69 , the average rating for aroma is 3.58 , the average rating for texture is 3.57 and the highest value for taste is 4.34 . Statistically, the results showed that the interaction between factors had a significant effect ( $\mathrm{P}$ 0.01) on the antioxidants produced. The concentration factor of mangosteen rind extract and peppermint oil had a significant effect (P 0.05) on the taste of the caramel candy.

Keywords: Caramel candy, Mangosteen peel, Peppermint oil 


\section{PENDAHULUAN}

Permen susu karamel merupakan salah satu makanan ringan yang berbahan utama susu, gula, air dan sirup fruktosa yang dicampur dengan perbandingan komposisi tertentu dan ditambahkan pewarna tergantung jenis permen yang diinginkan. Karakteristik permen susu karamel yang dihasilkan sangat dipengaruhi oleh jenis susu yang digunakan (Amir et al., 2017). Rofiah et al., (2014) menambahkan bahwa jumlah sukrosa dan sirup glukosa dapat mempengaruhi tekstur dari permen susu karamel. Campuran susu dan gula yang dipanaskan pada suhu tinggi serta pengadukan yang dilakukan terus menerus hingga mencapai proses karamelisasi disebut dengan permen karamel (Monica, 2020).

Dalam pembuatan permen susu karamel salah satu bahan yang dapat ditambahkan adalah kulit manggis. Kulit manggis adalah limbah dari buah manggis yang kaya akan manfaat. Kulit manggis mengandung senyawa antioksidan seperti senyawa fenolik. Kulit manggis dapat digunakan sebagai pewarna dan mengandung antioksidan. Haryanto, (2016).

Pada penelitian Nurlita (2019), pembuatan permen antioksidan dari ekstrak kulit manggis dan susu sapi dengan menggunakan ekstrak kulit manggis yang berbeda yaitu F1 0,5 gram, F2 0,2 gram dan F3 0,25 gram. Parameter uji yang dilakukan yaitu uji organoleptik (uji hedonik dan pengujian waktu larut). Hasil penelitian menunjukkan bahwa uji organoleptik dan uji waktu larut permen memenuhi kriteria uji permen susu karamel. Kriteria uji permen susu karamel dan uji waktu larut permen 5-10 menit, kemudian pada uji hedonik permen yang paling banyak disukai yaitu F2 dengan nilai berdasarkan tekstur 69, warna 70, aroma 71 dan rasa 77 dalam skala 0-100.Pada penelitian Mansur (2017) dengan menggunakan jumlah kulit manggis 150 gram, 200 gram dan 250 gram. Dalam penelitian tersebut dilakukan pengujian hedonik serta uji kesukaan dari permen.

Menurut Laoli (2019) penambahan peppermint pada permen digunakan untuk membantu menambah efek aroma dan rasa segar khas daun mint. Penambahan peppermint pada campuran permen karamel sebagai pemberi aroma baru dari permen karamel. Selain itu ekstrak minyak peppermint yang memiliki kandungan ester, seperti menthyl asetat, dapat menghasilkan aroma dan flavour minty dengan ciri khas aroma yang sangat kuat sehingga dapat digunakan sebagai bahan tambahan pangan (Marsendy, 2019). Komponen-komponen yang terdapat pada ekstrak daun Mentha peperita, L seperti menthone, $\alpha$-pineene, $\beta$-Pinene, isomenthone dan neomenthone (Golebioswski et al., 2008).

\section{METODE PENELITIAN}

Penelitian ini dilaksanakan di Penelitian ini dilaksanakan di Laboratorium Rekayasa Proses Pangan dan Industri, Laboratorium Analisis Pangan dan Hasil Pertanian dan Laboratorium Uji Sensori Jurusan Teknologi Hasil Pertanian Universitas Syiah Kuala.

\section{MATERI DAN METODE}

\section{Bahan Dan Alat}

Adapun bahan yang digunakan pada penelitian ini adalah susu sapi dengan merk ultra milk uht (kemasan) $300 \mathrm{ml}$, gula pasir $206 \mathrm{~g}$, mentega merk blueband $7 \mathrm{~g}$ dalam ekstrak kulit manggis sesuai perlakuan (50 gram, 60 gram dan 70 gram) yang buahnya dibeli dipasar Lambaro, peppermint oil merk Rabbani sesuai perlakuan (1 ml, $2 \mathrm{ml}$ dan $3 \mathrm{ml})$ dan DPPH (2,2- 
difenil-1-pikrilhidrazil), Aquades, $\mathrm{Na}_{2} \mathrm{CO}_{3}, \mathrm{~Pb}$ Asetat, Larutan Luff Schrool, $\mathrm{KI} 20 \%, \mathrm{H}_{2} \mathrm{SO}_{4}$ 26,5\%. Na-Thiosulfat 0,1 N, Pati $1 \%$.

Alat yang digunakan pada penelitian ini adalah wadah, kompor gas, pengaduk, timbangan digital, blender, pisau, baki/nampan, telenan, gelas ukur, wajan, panci, saringan. Sedangkan alat untuk analisis yang digunakan adalah desikator, oven, Muffle furnace (tanur), spektrofometer dan kuesioner untuk pengujian organoleptik.

\section{Rancangan Penelitian}

Penelitian ini menggunakan Rancangan Acak Lengkap (RAL) faktorial dengan 2 faktor, yaitu perbandingan penambahan ekstrak kulit manggis dan ekstrak peppermint. Penambahan konsentrasi ekstrak kulit manggis didapatkan berdasarkan hasil pra penelitian yang sebelumnya telah dilakukan. Faktor penambahan kulit manggis terdiri 3 (tiga) taraf, yaitu penambahan ekstrak kulit manggis $50 \mathrm{~g}$ (M1), $60 \mathrm{~g}$ (M2), $70 \mathrm{~g}$ (M3), sedangkan faktor kedua yaitu penambahan peppermint oil yang terdiri 3 (tiga taraf) yaitu $1 \mathrm{ml}(\mathrm{P} 1), 2 \mathrm{ml}(\mathrm{P} 2)$ dan $3 \mathrm{ml}(\mathrm{P} 3)$ dalam berat total bahan $522 \mathrm{~g}$. Dengan demikian kombinasi perlakuan yaitu $3 \times 3 \times 3=27$ dengan menggunakan 3 kali ulangan sehingga diperoleh 27 satuan percobaan.

\section{Analisis Data}

Data hasil penelitian diperoleh selanjutnya di anlisis menggunakan Analysis of varience (ANOVA). Apabila terdapat data yang pengaruh nyata pada perlakuan maka dilanjutkan dengan uji Duncan Multiple Range Test (DMRT).

\section{Prosedur Penelitian}

1. Pembuatan ekstrak kulit manggis

Dipisahkan kulit manggis (bagian luar dan dalam) dengan biji dan daging buah kemudian dicuci hingga bersih, lalu dilakukan pemblansiran dengan menggunakan hot water blanching dengan suhu $80^{\circ} \mathrm{C}$ selama 6 (enam) menit. Kulit lunak yang diperoleh kemudian dilakukan pemotongan, lalu kulit manggis ditimbang seberat 300 gram dan diblender dengan $500 \mathrm{ml}$ air, kemudian disaring dan dihasilkan ekstrak kulit manggis. Dilakukan pemanasan sampai suhu $100^{\circ} \mathrm{C}$ lalu ditambahkan gula sebanyak 26 gram (pada setiap perlakuan) ke dalam ekstrak kulit manggis sampai gula benar-benar larut.

2. Pembuatan Permen Karamel

Dipanaskan 7 gram mentega sampai meleleh pada suhu $33^{\circ} \mathrm{C}$. Dimasukkan susu $300 \mathrm{ml}$ ke dalam panci. Ditambahkan peppermint oil dan ekstrak kulit manggis sesuai perlakuan kemudian dipanaskan 15 menit pada suhu $100^{\circ} \mathrm{C}$ sampai diaduk lalu ditambahkan gula sebanyak 180 gram dan diaduk sampai mengental. Bahan yang sudah jadi dimasukkan kedalam nampan dan dibiarkan mengeras. Permen dipotong kecil-kecil sesuai sesuai ukuran yang diinginkan.

\section{Analisis Permen Karamel}

Adapun analisis yang digunakan pada permen caramel yaitu kadar air, kadar gula reduksi, kadar abu, uji aktifitas antioksidan dan analisis sensori yaitu uji organoleptik (hedonik) dari warna, rasa, aroma, rasa dan tekstur oleh panelis terlatih sebanyak 25 0rang. 


\section{HASIL DAN PEMBAHASAN}

\section{Kadar Air}

Hasil sidik ragam menunjukkan bahwa konsentrasi penambahan kulit manggis (M) dan peppermint oil $(\mathrm{P})$ dan interaksi keduanya berpengaruh tidak nyata $(\mathrm{P}>0,05)$ terhadap nilai kadar air permen susu karamel. Nilai rata-rata kadar air yang didapatkan pada penelitian ini yaitu $4,82 \%$. Berdasarkan hasil yang didapatkan, nilai rata-rata dari kadar air memenuhi kriteria SNI- 3547.2-2008 kembang gula lunak bukan jelly dengan kadar air maksimal 7,5\% dan yang termasuk jelly yaitu maksimal hingga $20 \%$.

Pada penelitian Sistanto et al., (2014) kadar air yang dihasilkan dari permen susu karamel dengan penambahan tepung temulawak dan jahe terdapat pada perlakuan penambahan tepung temulawak $0,6 \%$ dan jahe $8,50 \%$ dengan nilai kadar air tertinggi yaitu 10,68\%. Nilai tersebut lebih tinggi jika dibandingkan dengan nilai kadar air yang didapatkan pada penelitian ini. Pada penelitian Astuti et al. (2015) membuat permen susu, mendapatkan nilai kadar air dengan penambahan perbandingan sukrosa dan sirup glukosa yaitu sebesar 5,88 - 8,64\%.

\section{Gula Reduksi}

Hasil sidik ragam menunjukkan bahwa konsentrasi penambahan ekstrak kulit manggis $(\mathrm{M})$, penambahan peppermint oil $(\mathrm{P})$, dan interaksi keduanya tidak berpengaruh nyata $(\mathrm{P}>0,05)$ terhadap nilai gula reduksi permen karamel. Hasil penelitian menunjukkan bahwa kadar gula reduksi pada permen susu karamel memiliki nilai rata-rata keseluruhan persentase 2,19\%. Nilai tersebut memenuhi kriteria SNI 3547.2-2008 kembang gula lunak, kadar gula reduksi permen non jelly (karamel) maksimal $20 \%$.

Hasil penelitian ini sesuai dengan Kurniawati (2005) dalam Astuti et al, (2016) dengan kadar gula reduksi akan terus meningkat apabila penggunaan sirup glukosa yang ditambahkan lebih banyak. Kadar gula reduksi yang didapatkan pada permen jelly nenas tertinggi yaitu $12,7 \%$ dengan formulasi sukrosa $75 \%$ dan sirup glukosa $25 \%$. Sedangkan nilai kadar gula reduksi yang terendah yaitu 7,6\% dengan formulasi sukrosa $83,33 \%$ dan sirup glukosa $16,67 \%$.

\section{Kadar Abu}

Hasil sidik ragam menunjukkan bahwa konsentrasi penambahan kulit manggis (M) dan interaksi keduanya tidak berpengaruh nyata $(\mathrm{P}>0,05)$ terhadap nilai kadar abu permen karamel. Nilai rata-rata kadar abu pada penelitian ini yaitu $0,808 \%$, nilai tersebut sesuai dengan SNI3547.2-2008 kembang gula lunak, kadar abu permen yang non jelly (karamel) yaitu maksimal 2,0 .

\section{Kadar Antioksidan}

Hasil sidik ragam menunjukkan bahwa interaksi konsentrasi kulit manggis dan peppermint oil $(\mathrm{pm})$ berpengaruh nyata $(\mathrm{P} \leq 0,05)$ terhadap nilai aktivitas antioksidan permen karamel. Interaksi variabel yang diteliti terhadap nilai aktivitas antioksidan permen susu karamel dapat dilihat pada Gambar 1. 


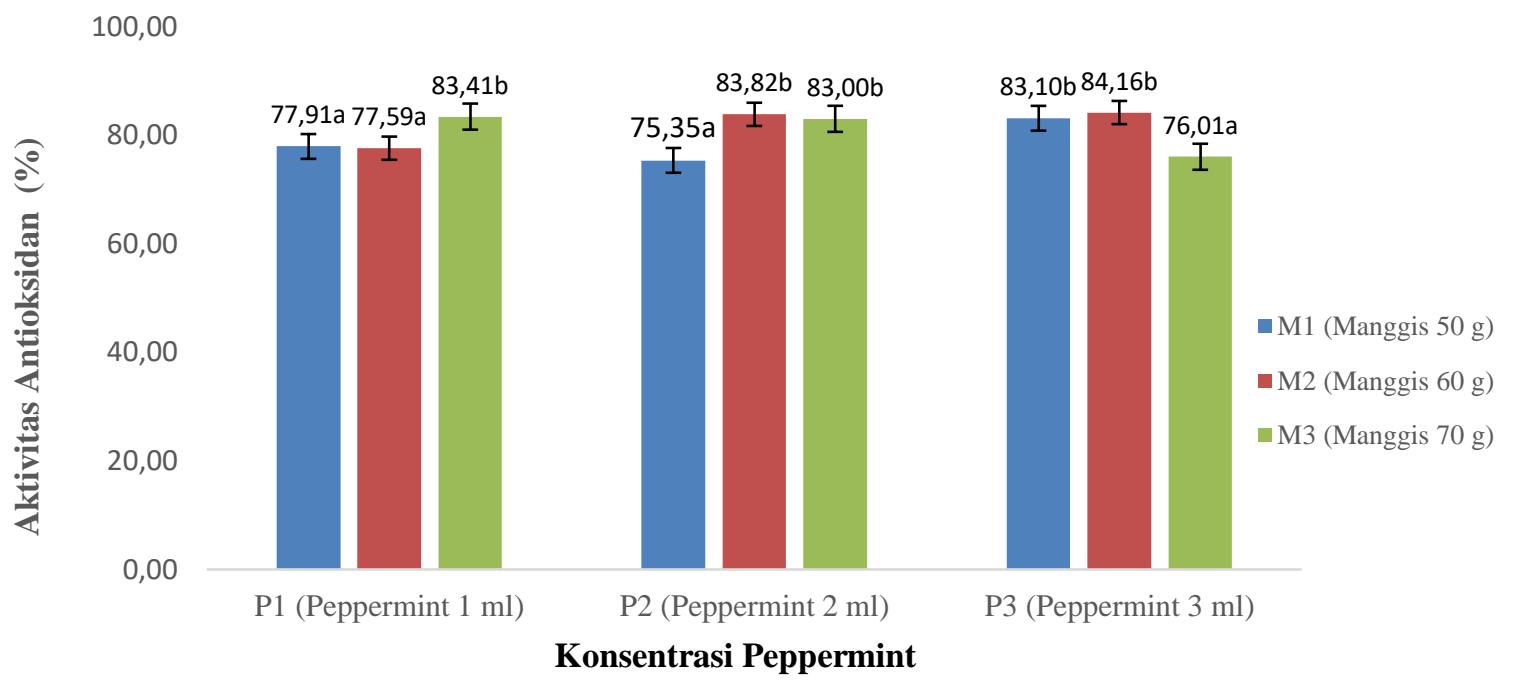

Gambar 1. Pengaruh Interaksi antara penambahan peppermint dan ekstrak kulit manggis terhadap nilai aktivitas antioksidan (nilai yang diikuti huruf menunjukkan perbedaan yang nyata pada uji DMRT $(0,05)$ taraf $2=$ $2,97, \operatorname{taraf} 3=3,12, \operatorname{taraf} 4=3,21$, taraf $5=3,27, \operatorname{taraf} 6=3,32, \operatorname{taraf} 7=3,36, \operatorname{taraf} 8=3,38, \operatorname{taraf} 9=3,4)$

Berdasarkan uji DMRT 0,05 Gambar 1 pada grafik tersebut, aktivitas antioksidan memiliki nilai antara $76,01 \%-84,16 \%$ dengan nilai rata-rata $80,48 \%$. Aktivitas antioksidan yang terkandung didalam permen tergolong cukup tinggi dengan nilai rerata $76,01 \%-84,16 \%$. Jika dibandingkan dengan penelitian Haryanto (2016) yang membuat bubuk kulit manggis menghasilkan aktivitas antioksidan sebesar 44,50\% - 66,25\%. Nugroho et al. (2015) membuat es krim dengan penambahan kulit manggis menghasilkan aktivitas antioksidan sebesar 97,98\%.

Diduga penambahan ekstrak kulit manggis yang lebih banyak dapat meningkatkan aktivitas antioksidan, sesuai dengan hasil penelitian Mansur (2017), dimana penggunaan kulit manggis 100 gram mengandung aktivitas antioksidan 19,45\%, 200 gram mengandung aktivitas antioksidan, 20,53\%, dan 250 gram mengandung aktivitas antioksidan 24,68\%. semakin banyak penggunaan kulit manggis dalam pembuatan permen jelly maka akan semakin tinggi kadar aktivitas antioksidan.

\section{Warna}

Warna adalah salah satu unsur yang menentukan tingkat penerimaan konsumen dari suatu produk. Warna menentukan penampilan produk terhadap sensori penglihatan oleh indera mata (Haryanti dan Zueni, 2015). Hasil Sidik ragam menunjukkan penambahan peppermint oil (P) dan penambahan ekstrak kulit manggis (M) serta interaksi keduanya berpengaruh tidak nyata $(\mathrm{P}>0,05)$ terhadap tingkat kesukaan warna permen susu karamel oleh panelis. Nilai ratarata dari keseluruhan yaitu 3,69 dengan keterangan suka.

\section{Aroma}

Aroma yang tersebar dari dalam makanan yang mempunyai daya tarik untuk merangsang indra penciuman sehingga dapat membangkitkan selera (Harahap, 2019). Menurut Winarno (2004) penilaian terhadap aroma dipengaruhi oleh faktor psikis dan fisiologis yang menimbulkan pendapat yang berlainan. Aroma merupakan salah satu hal yang dapat menarik selera konsumen. Hasil sidik ragam menunjukkan bahwa penambahan manggis (M) dan penambahan peppermint oil $(\mathrm{P})$ dan interaksi keduanya berpengaruh tidak nyata $(\mathrm{P}>0,05)$ terhadap penilaian aroma permen susu karamel oleh panelis. Nilai rata-rata keseluruhan dari uji aroma yaitu 3,58 dengan keterangan suka. 


\section{Tekstur}

Tekstur merupakan salah satu faktor yang berkaitan tentang sensori oleh indra peraba (kulit/tangan). Tekstur dinilai dari tingkat kelembutan dan kekerasan pada produk. Pada produk pangan, tekstur dapat dinilai oleh mulut dengan menggunakan lidah dan juga dapat menggunakan tangan. Kualitas suatu produk juga dapat dinilai dari tekstur produk tersebut (Kartika et al., 1988). Hasil sidik ragam pada menunjukkan bahwa penambahan ekstrak kulit manggis $(\mathrm{M})$ dan peppermint oil $(\mathrm{P})$ serta interaksi keduanya tidak berpengaruh nyata $(\mathrm{P}>0,05)$ terhadap tekstur dari permen karamel. Nilai rata-rata keseluruhan dari tekstur yaitu 3,57 dengan keterangan suka.

Sukrosa berfungsi dalam pembentukan tekstur, pemberi flavour melalui reaksi pencokelatan dan memberi rasa manis. Selain sukrosa/gula di beberapa industri permen, glukosa cair juga ditambahkan dalam pembuatan permen, sirup glukosa adalah cairan gula kental yang diperoleh dari pati (Zalizar, 2016).

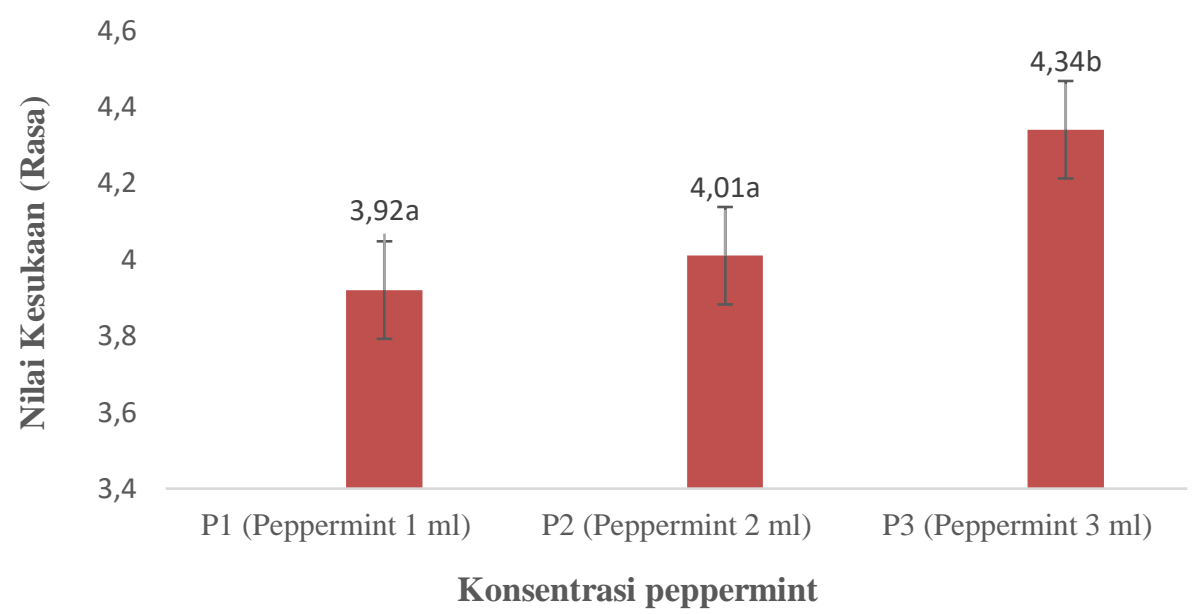

Gambar 2. Pengaruh penamabahan peppermint oil terhadap uji hedonik rasa (nilai yang diikuti huruf menunjukkan perbedaan yang nyata pada uji DMRT $(0.05)$ taraf 2=2,97, taraf 3=3,12) (Nilai $1=$ Sangat Tidak suka, $2=$ Tidak Suka, $3=$ Netral, 4= Suka dan 5=Sangat suka

Dalam proses pembentukan toksik Staphylococcus aureus membutuhkan ketersediaan air yang cukup, $\mathrm{pH}$ antara 5,0 sampai 6,5 dan protein yang cukup Staphylocccus aureus dapat memproduksi enzim seperti protease, lipase dan koagulase (Soejono 1999). Hal ini memungkinkan Staphylococcus aureus merombak protein dan lemak susu sehingga menyebabkan kerusakan komponen susu dan apabila jumlahnya telah melebihi $10^{6} \mathrm{cfu} / \mathrm{ml}$ tidak akan menyebabkan perubahan rasa dan sifat fisiknya .

\section{KESIMPULAN DAN SARAN}

\section{KESIMPULAN}

Rata-rata kadar air dan kadar abu sebesar 4,82\% dan 0,808\% Hasil yang didapatkan memenuhi SNI 3547.2-2008. Nilai rata-rata kadar gula reduksi pada permen karamel yaitu sebesar 2,19\%. Nilai aktivitas antioksidan diperoleh pada permen susu karamel yaitu berkisar antara $83,00-84,16 \%$. Nilai rata-rata untuk warna, aroma dan tekstur pada permen karamel yaitu sebesar 3,69, 3,58 dan 3,57 dengan keterangan suka. Rasa permen susu karamel yang paling disukai yaitu pada penambahan peppermint oil (P3) dengan skor 4,34. 


\section{SARAN}

Adapun saran untuk penelitian ini ialah melakukan penambahan bahan berupa sirup glukosa yang dapat meningkatkan viskositas dari permen serta dilakukan pengujian deskriptif agar lebih mendapatkan gambaran yang spesifik tentang karakteristik dari atribut sensori permen karamel

\section{DAFTAR PUSTAKA}

Amir, F., Noviani, E., dan Widari, N.S. 2017. Pembuatan Permen Susu Kambing Etawa Menggunakan Buah Kurma Sebagai Pengganti Gula. Teknik Waktu. 15 (2): 43-50.

Fardiaz S. 1989. Mikrobiologi Pengolahan Pangan. PAU Pangan dan Gizi. Institut Pertanian Bogor. Bogor .

Haryanto, B. 2016. Pengaruh Konsentrasi Putih Telur Terhadap Sifat Fisik, Kadar Antosianin Bubuk Instan Ekstrak Kulit Mangis (Garcinia Mangosta L) Dengan Metode Foam Mat Drying. Jurnal Kesehatan. 8 (1) : 1-8.

Haryanto, B. 2016. Pengaruh Konsentrasi Putih Telur Terhadap Sifat Fisik, Kadar Antosianin Bubuk Instan Ekstrak Kulit Mangis (Garcinia Mangosta L) Dengan Metode Foam Mat Drying. Jurnal Kesehatan. 8 (1) : 1-8.

Haryanti, N. Zueni, A. 2015. Identifikasi mutu fisik, kimia dan organoleptik es krim daging kulit manggis (Garcinia mangostana L.) dengan variasi susu krim. Agritepa. 1(2) : 143156.

Harahap, H. Z. 2019. Kandungan Senyawa Vitamin C dan Daya Terima Permen JellyKawista (Limonia acissima L). Skripsi. Universitas PKU Muhammadiyah, Surakarta.

Kurniawati, Y. 2005. Pengaruh Perbandingan Sirup Glukosa : Sukrosa Terhadap Sifat Kimia dan Permen Jelly Nanas, (Alnanas comusus (L) Mer) Selama Penyimpana. Skripsi. Jurusan Teknologi Hasl Pertanian Unoveristas Lampung Bandar Lampung.

Kartika, B., Hastuti, P dan Supartono, W. 1988. Pedoman Uji Inderawi Bahan Pangan. PAU Pangan dan Gizi-UGM, Yogyakarta.

Laoli, K. F. 2019. Pengaruh Penambahan Ekstrak Daun Peppermint (Mentha Piperita) Terhadap Tingkat Kesukaan Aroma dan Rasa Serta Aktivitas Antioksidan Permen Jelly Buah). Skripsi. Universitas Sanata Dharma, Yogyakarta.

Monica, C. Hintono, A. dan Mulyani, S. 2020. Kakarakteristik Permen Karamel Susu Kedelai Dengan Penambahan Jahe. . 4 (2) : 110-116.

Mansur, A. 2017. Pengaruh Perbedaan Massa Kulit Manggis Terhadap Kualitas Permen Jelly Kulit Manggis (Garciana Mangostana L.). Ilmiah Pariwisata. 13(1) : 1-17.

Nugroho, Y.A., dan Kusnadi, J. 2015. Aplikasi Kulit Manggis (Garcinia mangostana, L) Sebagai sumber Antioksidan Pada Es krim. Pangan dan Agroindustri. 3 (4) : 1263-1271.

Rofiah, A., dan Al-Mahfudhz. 2014. Kajian Dosis Sukrosa dan Sirup Glukosa Terhadap Kualitas Permen Karamel Susu. Nabati. 11 (1) : 55-65.

Sistanto., Soetrisno, E., dan Saepudin, R. 2014. Sifat Fisikokimia dan OrganoleptikPermen Susu (Karamel ) Rasa Jahe (Zingiber Officinale Roscoe) dan Temulawak(Curcuma xanthorriza Roxb) Taste. Sains Peternakan Indonesia, 9 (2) $\quad$ : 81-90.

Zalizar, L., Sapitri, E,M., Putri, N.M., Nurrahman, G, W., dan Nisa., L.M.K. 2016. Perbandingan Penambahan Glukosa Dan Sukrosa Terhadap Kualitas Permen Susu Kambing Peranan Etawa (PE) Berdasarkan Preferensi Konsumsi. Seminar Nasional Gelar Produk. 